\title{
Peptidomimetic Fluoromethylketone Rescues Mice from Lethal Endotoxic Shock
}

\author{
Stephen R. Grobmyer, Robert C. Armstrong, ${ }^{2}$ \\ Susan C. Nicholson, ${ }^{3}$ Cem Gabay, ${ }^{4}$ William P. Arend, \\ Strite H. Potter, ${ }^{5}$ Maxine Melchior, ${ }^{5}$ Lawrence C. Fritz, $^{2}$ and \\ Carl F. Nathan ${ }^{3,5}$ \\ Departments of ${ }^{1}$ Surgery, ${ }^{3}$ Medicine, and ${ }^{5}$ Microbiology and \\ Immunology, Weill Medical College of Cornell University, New York, \\ New York, U.S.A. \\ ${ }^{2}$ Idun Pharmaceuticals, Inc., La Jolla, California, U.S.A. \\ ${ }^{4}$ Department of Medicine-Division of Rheumatology, University of \\ Colorado Health Sciences Center, Denver, Colorado, U.S.A. \\ Communicated by C. Nathan. Accepted August 17, 1999.
}

\begin{abstract}
Background: Septic shock is a leading cause of mortality in intensive care units. No new interventions in the last 20 years have made a substantial impact on the outcome of patients with septic shock. Identification of inhibitable pathways that mediate death in shock is an important goal.

Materials and Methods: Two novel caspase inhibitors, (2-indolyl)-carbonyl-Ala-Asp-fluoromethylketone (IDN 1529) and (1-methyl-3-methyl-2-indolyl)-carbonyl-ValAsp-fluoromethylketone (IDN 1965), were studied in a murine model of endotoxic shock.

Results: IDN 1529 prolonged survival when given before or up to $3 \mathrm{hr}$ after high-dose LPS $(p<0.01)$ and increased by 2.2 -fold the number of animals surviving longterm after a lower dose of LPS $(p<0.01)$. Despite its
\end{abstract}

similar chemical structure, IDN 1965 lacked these protective effects. Both compounds inhibited caspases 1, 2, $3,6,8$, and 9 , and both afforded comparable reduction in Fas- and LPS-induced caspase 3-like activity and apoptosis. Paradoxically, administration of IDN 1529 but not IDN 1965 led to an increase in the LPS-induced elevation of serum cytokines related directly (IL-1 $\beta, \mathrm{IL}-18)$ or indirectly (IL-l $\alpha, \mathrm{IL}-1 \mathrm{Ra})$ to the action of caspase 1 .

Conclusions: A process that appears to be distinct from both apoptosis and the release of inflammatory cytokines is a late-acting requirement for lethality in endotoxic shock. Inhibition of this process can rescue mice even when therapy is initiated after LPS has made the mice severely ill.

\section{Introduction}

The failure of clinical trials aimed at the treatment of septic shock (1) could have been predicted from animal models in which the interventions were effective prophylactically but not

Address correspondence and reprint requests to: Dr. Carl Nathan, Weill Medical College of Cornell University, Box 57, 1300 York Ave., New York, NY 10021, U.S.A. Phone: 212-746-2985; Fax: 212-746-8536; E-mail:

cnathan@mail.med.cornell.edu when administered after a lethal challenge with bacteria or bacterial components. These clinical and experimental lessons suggest that key molecular mediators remain to be identified in the chain of events leading to death in endotoxemia and sepsis.

Caspases are highly conserved intracellular proteases involved in processing inflammatory cytokines and executing apoptosis (reviewed in refs. 2,3). Caspase 1 [interleukin- $1 \beta$ (IL- $1 \beta$ )- 
converting enzyme] processes both pro-IL- $1 \beta$ $(4-6)$ and pro-IL-18 $(7,8)$. Mouse caspase 11 helps activate caspase 1 and probably corresponds to human caspases 4 and $5(6)$. That mice lacking caspase $1(4,5)$ or caspase $11(6)$ are resistant to the lethality of endotoxic bacterial lipopolysaccharide (LPS) has been attributed to their decreased production of IL- $1 \beta$, IL- $1 \alpha$, IL18 , and inteferon $\gamma($ IFN- $\gamma)(4,7,8)$. Low IFN- $\gamma$ was considered secondary to low levels of IL-18, an IFN- $\gamma$-releasing factor, while the dependence of IL- $1 \alpha$ production on caspase 1 remains unexplained. In contrast, it is not clear to what extent apoptosis contributes to mortality in endotoxic shock. Injection of LPS induced apoptosis in mouse liver, spleen, intestine, liver, lung, and thymus $(9-12)$, primarily in endothelial cells, but to a much lesser extent than injection of anti-FAS monoclonal antibody (MAb) (13) or the combination of D-galactosamine and LPS (14).

Here, we compared the effects in endotoxic shock of two closely related peptidomimetic fluoromethylketones, IDN 1529 and IDN 1965. Both compounds inhibited caspases and markedly reduced hepatic injury in mice challenged with anti-Fas MAb. Both agents also reduced caspase 3-like activity and apoptosis induced by LPS. However, only IDN 1529 protected mice from the lethality of LPS. The protection afforded by IDN 1529 was associated with elevation rather than suppression of the products of caspase 1. Most important, IDN 1529 was effective when administered after the onset of shock.

\section{Materials and Methods}

Caspase Inhibitors

Reagents were from Sigma Chemical Co. (St. Louis, MO) unless indicated otherwise. IDN 1529 and IDN 1965 were provided by IDUN Pharmaceuticals. Recombinant mouse caspase 1 and human caspases $2,3,6,8$, and 9 were cloned into pET3a or pET2 $1 \mathrm{~b}$ expression vectors as hexahistidine fusion proteins (Novagen, Madison, WI), expressed in E. coli strain BL21, purified by $\mathrm{Ni}^{+}$chelation chromotography, and characterized by fluorescence-based assays $(15,16)$. Macrophages were elicited by intraperitoneal (ip) injection of 1 $\mathrm{ml}$ of $10 \%$ sterile protease peptone, collected by peritoneal lavage 4 days later, and plated at $10^{6}$ cells/well in RPMI with $10 \%$ heat-inactivated fetal calf serum (FCS) (HyClone Laboratories, Logan, UT), $1 \%$ penicillin-streptomycin, and $2 \%$
L-glutamine (JRH Biosciences, Lenexa, KS). Cells were allowed to adhere for $2 \mathrm{hr}$ at $37^{\circ} \mathrm{C}$ and the washed monolayer was exposed to $10 \mathrm{ng} / \mathrm{ml} \mathrm{Sal}$ monella typhimurium LPS (Difco Laboratories, Detroit, MI) for $4 \mathrm{hr}$ in the presence of indicated concentrations of inhibitors. Cells were washed again and exposed to nigericin $(10 \mu \mathrm{M})$ (17) or ATP ( $5 \mathrm{mM}$ ) (18) for $20 \mathrm{~min}$ and IL- $1 \beta$ concentrations determined in the conditioned media by ELISA ( $R$ and D Systems, Minneapolis, MN).

\section{Survival Studies}

Following institutionally approved protocols, 8to 12-week old male and female C57BL/6 mice (Taconic, Germantown, NY; Charles River Laboratories, Wilmington, MA) were challenged ip with 200 or $500 \mu \mathrm{g}$ of LPS in $100 \mu \mathrm{l}$ sterile $1 \%$ bovine serum albumin (BSA) (low LPS) in $0.9 \%$ saline (Abbott Labs, Chicago, IL) (vehicle 1) or with the same volume of vehicle 1 alone. Mice were additionally injected ip with test compounds in $100 \mu \mathrm{l}$ of vehicle $2[20 \%$ or $50 \%$ dimethylsulfoxide (DMSO) in $0.9 \%$ sterile saline] or with vehicle 2 alone. Survival was monitored hourly from 8 a.m. until midnight, from 6 a.m. the following day until midnight, from 6 a.m. until 8 p.m. the third day $(72 \mathrm{hr})$, and once daily for 3 weeks.

\section{Serum Cytokines}

Female (4) 8- to 12-week old C57BL/6 mice (Taconic; Charles River; Harlan Sprague Dawley, Indianapolis, IN; or Jackson Laboratories, Bar Harbor, ME) were challenged with LPS $(500 \mu \mathrm{g})$ or vehicle $1 \mathrm{ip}$. One hour later, drug or vehicle 2 was administered. At the times indicated in the legend to Figure 3, mice were asphyxiated with $\mathrm{CO}_{2}$ and serum collected for ELISAs [IL-1 $\beta$, IL$1 \alpha$, tumor necrosis factor (TNF), and IFN- $\gamma$ from $\mathrm{R}$ and D Systems; IL-1Ra as described (19); and serum amyloid A (SAA) as described (20)]. AntiSAA2 antibodies and SAA standards were kindly provided by Dr. J. Sipe. An ELISA for IL-18 was devised using $1 \times 8$ strip well high-binding plates (Costar, Cambridge, MA) coated overnight at $4^{\circ} \mathrm{C}$ with rat anti-mouse IL- 18 at $2 \mu \mathrm{g} / \mathrm{ml}$ in carbonate buffer, $\mathrm{pH}$ 9.5. Plates were washed three times with $0.05 \%$ Tween-20 in phosphatebuffered saline (PBS), blocked with 1\% BSA, 5\% sucrose, $0.05 \% \mathrm{NaN}_{3}$ in PBS for $2 \mathrm{hr}$ at room temperature, and washed. Serum samples were diluted $1: 5$ in PBS containing $0.05 \%$ Tween-20, $0.1 \%$ BSA. Standard curves $(0-1000 \mathrm{pg} / \mathrm{ml})$ 
were prepared using recombinant mouse IL-18 ( $R$ and D Systems) in $20 \%$ normal mouse serum. Samples were incubated for $2 \mathrm{hr}$ at room temperature. The plates were washed three times, incubated for $2 \mathrm{hr}$ with $250 \mathrm{ng} / \mathrm{ml}$ biotinylated goat anti-mouse IL-18 antibody ( $R$ and D Systems), and washed three times. Horseradish peroxidase-conjugated strepavidin (1:1000) (R and D Systems) was added for $20 \mathrm{~min}$ and the plates again washed three times. TMB (KPL Labs, Gaithersburg, $\mathrm{MD}$ ) was added for $10 \mathrm{~min}$ and the reaction stopped with $2 \mathrm{~N} \mathrm{H}_{2} \mathrm{SO}_{4}$ for determination of $\mathrm{OD}_{450}$. Approximate limits of sensitivity were as follows: TNF, $6 \mathrm{pg} / \mathrm{ml}$; IL- $1 \beta, 6 \mathrm{pg} / \mathrm{ml}$; IL- $1 \alpha, 15 \mathrm{pg} / \mathrm{ml}$; IFN- $\gamma, 2 \mathrm{pg} / \mathrm{ml}$; IL- $18,30 \mathrm{pg} / \mathrm{ml}$; IL-1Ra, $156 \mathrm{pg} / \mathrm{ml}$. Readings below the limit of detection were assigned a value of 0 . For characterization of the processed state of IL- $1 \beta$ and IL-18, sera were pooled from 5 to 6 mice sacrificed $3 \mathrm{hr}$ following LPS challenge, diluted $1: 1$ with radioimmunoprecipitation assay (RIPA) buffer $(50 \mathrm{mM}$ Tris- $\mathrm{HCl}, \mathrm{pH} 7.9 ; 100 \mathrm{mM} \mathrm{NaCl}$; $0.1 \%$ Triton X-100; 1 mM EDTA; $5 \mu \mathrm{g} / \mathrm{ml}$ PMSF; $5 \mu \mathrm{g} / \mathrm{ml}$ leupeptin; $5 \mu \mathrm{g} / \mathrm{ml}$ pepstatin; $5 \mu \mathrm{g} / \mathrm{ml}$ chymostatin; $5 \mu \mathrm{g} / \mathrm{ml}$ aprotinin), pre-cleared on protein G Sepharose beads (Amersham Pharmacia, Uppsala, Sweden) overnight at $4^{\circ} \mathrm{C}$, and immunoprecipitated with protein $G$ Sepharose beads and $1.5 \mu \mathrm{g}$ affinity-purified goat antimouse IL- $1 \beta$ antibody (R and D Systems) or 1.5 $\mu \mathrm{g}$ affinity-purified rat anti-mouse IL-18 MAb ( $R$ and D Systems). Immunoprecipitates were electrophoresed on $12 \%$ or $15 \%$ polyacylamide gels under reducing conditions, transferred to nitrocellulose, and immunoblotted with the same antibody used for immunoprecipitation as detected with peroxidase-conjugated rabbit anti-goat antibody or goat anti-rat antibody, each Fc fragment-specific (Jackson Immunoresearch). ProIL-1 $\beta$ (17) and pro-IL-18 were generated by exposure of macrophages to LPS for $3 \mathrm{hr}$.

\section{TUNEL, Liver Function Tests, and Tissue Caspase Assays}

Livers were fixed in $4 \%$ paraformaldehyde in PBS, pH 7.4 for $48 \mathrm{hr}$ and paraffin embedded. Five-micron sections were subjected to TUNEL (MBL Co., Nagoya, Japan) according to the manufacturer's instructions. The Vectastain Elite $\mathrm{ABC}$ kit (Vector Laboratories, Burlingame, CA) was used with 3,3'-diaminobenzidine (Vector) as substrate and Mayer's hematoxylin as counterstain. Positive cells per high-power field (HPF) $(\times 400)$ in 20 fields per slide were counted inde- pendently by two blinded observers. Serum glutamic-pyruvic transaminase (SGPT) was measured using a diagnostic kit (Sigma) on sera collected $11 \mathrm{hr}$ after LPS challenge and results expressed in Sigma-Frankel units $/ \mathrm{ml}$. For caspase assay, livers were homogenized in $0.5 \mathrm{ml}$ buffer A (10 mM HEPES, pH 7.4; $42 \mathrm{mM} \mathrm{KCL;} 5$ $\mathrm{mM} \mathrm{MgCl} 2 ; 1 \mathrm{mM}$ PMSF; $0.1 \mathrm{mM}$ EDTA; $0.1 \mathrm{mM}$ EGTA; $1 \mathrm{mM} \mathrm{DTT;} 1 \mu \mathrm{g} / \mathrm{ml}$ leupeptin; $5 \mu \mathrm{g} / \mathrm{ml}$ aprotinin; $0.5 \%$ CHAPS). The homogenate was centrifuged at $14,000 \times g$ for $15 \mathrm{~min}$ and duplicate samples of supernate containing $100 \mu \mathrm{g}$ of protein were brought to $100 \mu \mathrm{l}$ with buffer B (25 mM HEPES; 1 mM EDTA; 0.1\% CHAPS; $10 \%$ sucrose; $3 \mathrm{mM}$ DTT, pH 7.5). DEVD-AMC was added to a final concentration of $10 \mu \mathrm{M}$ in $100 \mu \mathrm{l}$ of buffer B. Fluorescence (excitation $360 \mathrm{nM}$, emission 460) was recorded over time.

\section{Statistical Analysis}

Survival differences were analyzed by log-rank comparisons of Kaplan-Meier curves using Statview 4.5 software (Abacus Concepts, Berkeley, CA). Results for serum cytokines, organ DEVDAMCase levels, serum SGPT, and TUNEL positivity are presented as means \pm SEM and compared using the nonparametric Kruskal-Wallis and Mann-Whitney U tests. A value of $p<0.05$ was considered statistically significant. All results mentioned were statistically significant unless stated otherwise.

\section{Results \\ Effects of IDN 1529 and IDN 1965 on Recombinant Caspases and IL-1 $\beta$ Release from Macrophages}

IDN 1529 and IDN 1965 (Fig. 1A) both inhibited recombinant mouse caspase 1 and human caspases $2,3,6,8$, and 9 with considerable potency (Fig. 1B), as determined in assays that monitored the cleavage of specific fluorogenic substrates $(15,16,21)$. The $K_{i}$ for inhibition of caspase 1 was substantially lower for IDN 1529 than for IDN 1965. Caspase 1 in intact, LPStreated macrophages was inhibited by both compounds, as evidenced by the dose-dependent decrease in the release of IL-1 $\beta$ (Fig. 1C). In intact cells, the inhibitory potency was lower than against the isolated enzyme, and the inhibitory profiles of the two agents were more closely comparable. Results were similar when the human monocytic cell line THP-1 was substituted for mouse macrophages (not shown). 


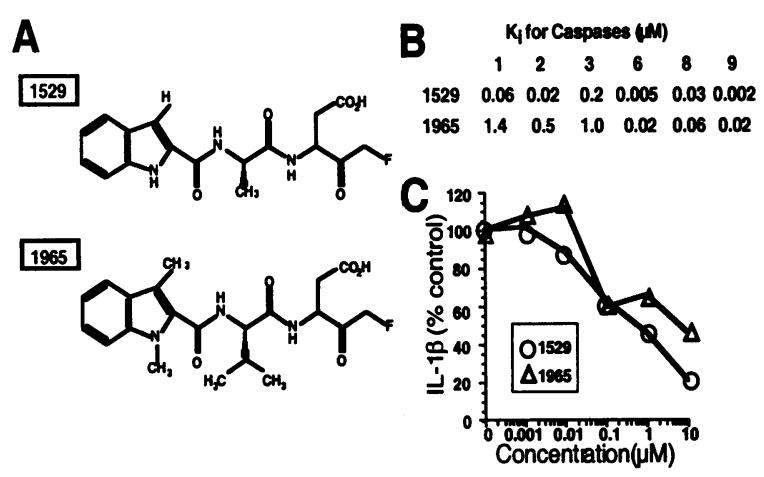

Fig. 1. Structures and caspase-inhibitory activities of compounds IDN 1529 and IDN 1965. (A) Structures. (B) Inhibitory constants determined against pure, recombinant mouse caspase 1 and human caspases 3, 6, and 8. (C) Inhibition of caspase 1 within primary macrophages. Peptone-elicited mouse peritoneal macrophages $\left(10^{6} /\right.$ well) were stimulated with LPS $(10 \mathrm{ng} / \mathrm{ml})$ for $4 \mathrm{hr}$ in the presence of indicated concentrations of inhibitor. Cells were then exposed to nigericin $(10 \mu \mathrm{M})$ for $20 \mathrm{~min}$. IL-1 $\beta$ in the conditioned media was measured by ELISA. With vehicle instead of inhibitor, IL- $1 \beta$ averaged $14.8 \mathrm{ng} / \mathrm{ml}$. Results are from a representative experiment performed in duplicate.

\section{Effect of Peptidomimetic Fluoromethylketones on Survival in Endotoxic Shock}

Both IDN 1529 and IDN 1965 protected mice from liver injury $\left(\mathrm{ED}_{50}=0.1 \mathrm{mg} / \mathrm{kg}\right.$ and 0.08 $\mathrm{mg} / \mathrm{kg}$, respectively) following the administration of Jo-2, a Fas agonist antibody (not shown). This encouraged us to study the same compounds in mice given a single large dose $(500 \mu \mathrm{g})$ of LPS (12). Administration of high-dose LPS reproduces many of the hemodynamic and metabolic changes seen in clinical septic shock. Hypotension (22), hypomotility, huddling, and ruffling of the coat are manifest within the first several hours following LPS challenge.

IDN 1529, but not IDN 1965, prolonged survival in mice challenged with $500 \mu \mathrm{g}$ of LPS (Fig. 2A-C). Survival was prolonged when IDN 1529 was administered in 3 doses $4 \mathrm{hr}$ apart, beginning either $0.5 \mathrm{hr}$ prior to LPS challenge (Fig. 2A), $1 \mathrm{hr}$ following LPS challenge (Fig. 2B), or as late as $3 \mathrm{hr}$ following LPS challenge (Fig. 2C). The efficacy of IDN 1529 when the first dose is given later than $3 \mathrm{hr}$ after LPS has not been studied.

When mice received a lower dose of LPS $(200 \mu \mathrm{g})$, there was improvement in overall survival, from $35 \%$ to $77 \%$, when IDN 1529 was administered in 3 doses $4 \mathrm{hr}$ apart, beginning 1

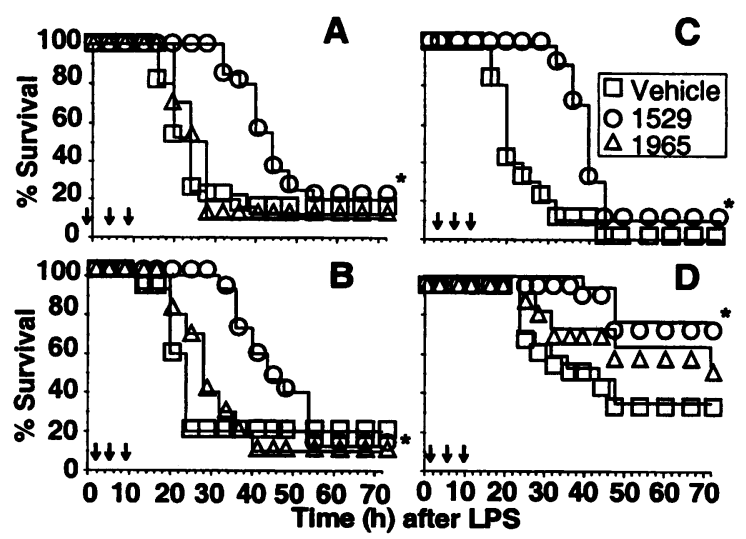

Fig. 2. Effect of peptidomimetic fluoromethylketones on survival of mice following LPS challenge. Mice were injected ip with $500 \mu \mathrm{g}$ $(\mathrm{A}-\mathrm{C})$ or $200 \mu \mathrm{g}$ (D) of LPS at time 0 . (A-D) Treatments at times indicated by arrows: $(\square)$, vehicle 2 (see Materials and Methods); (O), IDN 1529 (10 $\mathrm{mg} / \mathrm{kg}$ per injection in vehicle 2); ( $\triangle$ ), IDN 1965 (10 $\mathrm{mg} / \mathrm{kg}$ per injection in vehicle 2 ). Asterisks denote statistically significant differences for outcome of treatment with IDN 1529 compared to treatment with vehicle $(\mathrm{A}, p<0.01 ; \mathrm{B}, p<0.01 ; \mathrm{C}, p<0.01$, $\mathrm{D}, p<0.01)$. In no case was there a statistically significant difference between outcomes for mice treated with IDN 1965 or with vehicle. (A) Treatment with peptidomimetic fluoromethylketones started $0.5 \mathrm{hr}$ before LPS. Results are pooled for the following numbers of mice in four independent experiments: $(\square), 25 ;(O), 20 ;(\triangle)$, 10. (B) Treatment with peptidomimetic fluoromethylketones started 1 $\mathrm{hr}$ after LPS. Results are pooled for the following numbers of mice in three independent experiments: ( $\square), 15 ;(O), 15 ;(\triangle), 10$. (C) Treatment with peptidomimetic fluoromethylketones started $3 \mathrm{hr}$ after LPS. Results are pooled for the following numbers of mice in two independent experiments: $(\square), 10$; (O), 10. (D) Treatment with peptidomimetic fluoromethylketones started $1 \mathrm{hr}$ after LPS. Results are pooled for the following numbers of mice in three independent experiments: $(\square), 17 ;(\bigcirc), 17 ;(\triangle) 17$.

hr after the LPS challenge (Fig. 2D). There were no late deaths when the $72-\mathrm{hr}$ survivors were followed for up to 3 weeks (not shown).

In all experiments, each regimen was compared to a control group that received equal amounts of the DMSO-containing vehicle on the same schedule. At neither $500 \mu \mathrm{g}$ nor $200 \mu \mathrm{g}$ of LPS did survival in vehicle-treated mice differ significantly from survival in mice given saline in place of vehicle (not shown).

Blood pressure was not measured in the present studies because anesthesia and arterial cannulation (22) or heating for plethysmography (23) interfere with assessment of survival. However, the initial external signs of endotoxic shock 
(see above) were indistinguishable with respect to time of onset and severity in all treatment groups and with both doses of LPS.

\section{Effects on Serum Cytokines}

IL- $1 \beta$ AND IL- $1 \alpha$. Given the relative resistance of caspase $1^{-1-}$ mice to LPS $(4,5)$, the attribution of this phenotype to the lack of LPS-induced elevation of IL- $1 \beta$ and IL- $1 \alpha(4,5)$, and the ability of IDN 1529 to inhibit caspase 1, we hypothesized that the survival benefit afforded by IDN 1529 in LPS-challenged wild-type mice might result from blunting of the LPS-induced increase in IL-1. It was possible that IDN 1529 was more efficacious than IDN 1965 in blocking pro-IL-1 $\beta$ processing in vivo, even though both were efficacious in cell culture (Fig. 1C). However, administration of IDN 1529 had the opposite effect: it led to a synergistic elevation in serum IL- $1 \beta$ and IL- $1 \alpha$. IDN 1965 lacked this effect (Fig. 3A,B). Without LPS, neither IDN 1529 nor IDN 1965 increased cytokine levels. The elevation in serum IL-1 $\beta$ afforded by the combination of IDN 1529 plus LPS was a monotonic function of the dose of IDN 1529 over the range tested, from $0.1 \mathrm{mg} / \mathrm{kg}$ to 10 $\mathrm{mg} / \mathrm{kg}$ (Fig. 3C); at no dose of IDN 1529 was serum IL- $1 \beta$ lower than with LPS alone. Administration of IDN 1529 also led to an elevation in serum IL- $1 \beta$ and IL- $1 \alpha$ when the LPS dose was lowered to $200 \mu \mathrm{g}$ and when IDN 1529 was given either before or after LPS $(500 \mu \mathrm{g}$ ) (not shown).

As pro-IL- $1 \beta$ is much less bioactive than mature IL-1 $\beta$ (reviewed in ref. 24), we hypothesized that the immunoreactive IL- $1 \beta$ measured in the serum might consist solely of pro-IL-1 $\beta$. IL- $1 \beta$ in the serum of LPS-challenged, IDN 1529-treated mice was immunoprecipitated, electrophoresed, and immunoblotted. This revealed a marked increase not only in pro-IL- $1 \beta$ but also in mature IL-1 $\beta$ (Fig. 4A). Thus, the combination of LPS and IDN 1529 appears to foster extracellular release of the pro form, a portion of which is then processed, presumably by a caspase 1 -independent route, as described in other settings $(25-27)$.

IL-1Ra AND SAA. Since IL- $1 \beta$ and IL- $1 \alpha$ were increased in the setting of diminished lethality of LPS but themselves would be expected to contribute to the lethality of LPS (reviewed in ref. 24), we speculated that their effects might be antagonized by a compensatory increase in se-

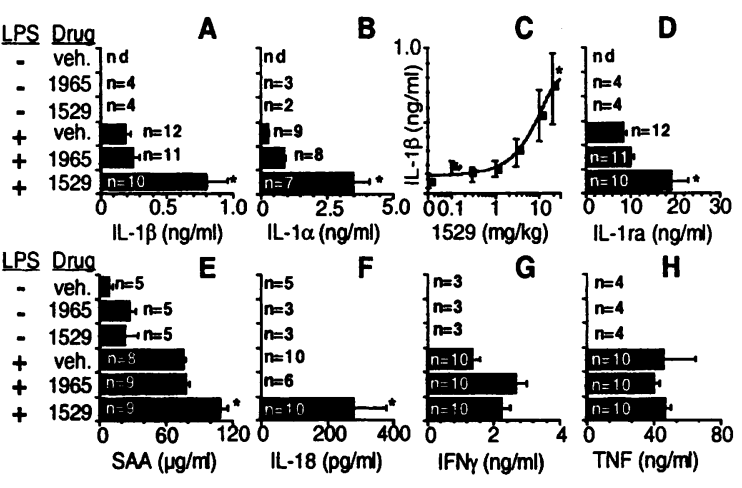

Fig. 3. Effect of peptidomimetic fluoromethylketones on serum cytokines. Mice were challenged ip with vehicle 1 (-; see Materials and Methods) or LPS (+; $500 \mu \mathrm{g}$ in vehicle 1 ), followed $1 \mathrm{hr}$ later by peptidomimetic fluoromethylketones $(10$ $\mathrm{mg} / \mathrm{kg}$, except for C, where doses were varied as shown, given in vehicle 2; see Materials and Methods) or vehicle 2 alone (veh.). Mice were sacrificed at the following times after LPS challenge for serum cytokine measurements: $1.5 \mathrm{hr}$, TNF (H); $3 \mathrm{hr}, \mathrm{IL}-1 \beta$ (A), IL-1 $\alpha$ (B), IL-l ra (D), IL-18 (F), SAA (E); 5 hr, IFN- $\gamma(\mathrm{G}) . n=$ mice per group, pooled from the following number of independent experiments: (A), 3; (B), 3; (D), 3; (E), 2; (F), 3; (G), 2; (H), 2. Asterisks denote statistical significance $(p<0.05)$ compared to LPS-challenged, vehicle-treated mice. (C) Dose-response effect of IDN 1529 on LPS-induced elevation in serum IL-1 $\beta$; means \pm SEM for 8 mice per time point.

cretion of their natural antagonist, IL-1Ra (28). Indeed, induction of serum IL-1Ra by LPS was synergistically augmented by the administration of IDN 1529, but not by IDN 1965 (Fig. 3D).

Two considerations argued, however, that the improved survival afforded by IDN 1529 did not result from IL-1Ra antagonizing IL- $1 \beta$ and IL- $1 \alpha$. First, the 8 -fold molar excess of serum IL-1Ra over the sum of serum IL- $1 \beta$ and IL- $1 \alpha$ in the serum of mice challenged with LPS and treated with IDN 1529 was far below the $>25$ fold excess required for effective antagonism (29). Second, the survival-extending effect of IDN 1529 was not diminished by administration of $1 \mathrm{mg} / \mathrm{kg}$ of a neutralizing goat anti-mouse IL-1Ra antibody (not shown). An ELISA for goat IgG demonstrated that the antibody persisted in the circulation of LPS-challenged, IDN 1529treated mice at $>10 \mu \mathrm{g} / \mathrm{ml}$ for $>9 \mathrm{hr}$, a concentration far exceeding the amount needed to neutralize the measured level of IL-IRa in vitro.

Serum levels of another acute-phase reactant, SAA, were also increased by the combination of LPS and IDN 1529 (Fig. 3E). In this case, 


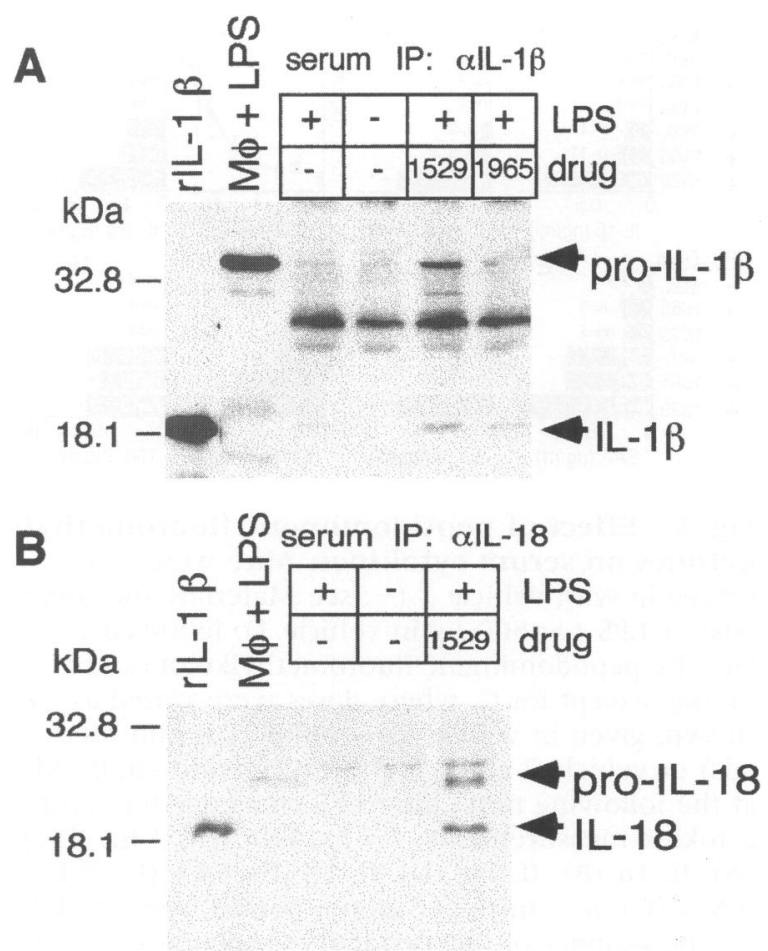

Fig. 4. Analysis of processed state of products of caspase 1. Mice (5-6 per group) were challenged with LPS (500 $\mu$ g i.p.) followed $1 \mathrm{hr}$ later by treatment with IDN 1529, IDN 1965, or vehicle 2 . Sera were collected $3 \mathrm{hr}$ after LPS administration, pooled, immunoprecipitated, and immunoblotted with antibodies against mouse IL-1 $\beta$ (A) or IL-18 (B). In A, standards included rIL-1 $\beta$ and lysate from peritoneal macrophages exposed to LPS in vitro for 4 hr as a source of pro-IL- $1 \beta$. In B, standards included rIL-18 and macrophage lysate prepared as in $\mathrm{A}$ as a source of pro-IL-18. (A,B) Bands migrating at $\sim 27$ $\mathrm{kD}$ represent light chain from the antibodies used for immunoprecipitation. Experiments were performed twice with similar results.

however, small elevations accompanied the administration of IDN 1529 alone, so that the effect of IDN 1529 plus LPS was not synergistic.

IL-18 AND IFN- $\gamma$. Pro-IL-18, like pro-IL-1 $\beta$, lacks a signal peptide (reviewed in ref. 30) and is cleaved by caspase 1 to generate mature, biologically active IL-18 $(7,8)$. As for IL-1, serum IL-18 concentrations were synergistically elevated by the combination of LPS and IDN 1529, but not by the combination of LPS and IDN 1965 (Fig. 3F). Indeed, IL-18 was below the level of detection in mice given either LPS alone or IDN 1529 alone (Fig. 3F). Pro-IL 18 is much less bioactive than mature IL-18 (31). Since IL-18 induces IFN- $\gamma(7,8)$ and IFN- $\gamma$ contributes to the lethality of LPS (32), and given that the IDN 1529-treated mice survived endotoxic shock better than vehicle-treated mice, we hypothesized that the immunoreactive $\mathrm{IL}-18$ in the circulation might consist solely of the pro-form. However, immunoprecipitation of serum from LPS-challenged, IDN 1529-treated mice followed by immunoblot demonstrated increased concentrations of both pro-IL-18 and mature IL-18 (Fig. 4B).

Since mature IL-18 was increased, we measured serum levels of IFN- $\gamma$. IFN- $\gamma$ was elevated in the serum of LPS-challenged mice treated with either IDN 1529 or IDN 1965, but the increases associated with the peptidomimetic fluoromethylketones were not statistically significant (Fig. 3G).

TNF. Neither IDN 1529 nor IDN 1965 had a detectable effect on LPS-induced elevations of the serum levels of this early-acting mediator of endotoxic lethality (Fig. 3H) (33).

\section{Liver Damage, Apoptosis, and Caspase 3-like} Activity

Challenge with LPS led to an increase in serum levels of the hepatocyte transaminase SGPT $(29 \pm 13 \mathrm{U} / \mathrm{ml}$ in 7 normal mice, rising to $86 \pm$ $23 \mathrm{U} / \mathrm{ml}$ in $8 \mathrm{LPS}$-challenged mice), but the rise was far less than in mice given $10 \mu \mathrm{g}$ of anti-Fas antibody $\left(6 \times 10^{4} \mathrm{U} / \mathrm{ml} \pm 4.4 \times 10^{3}\right.$ in 5 mice $)$. Both IDN 1529 (10 mg/kg) and IDN 1965 (10 $\mathrm{mg} / \mathrm{kg}$ ) completely prevented the increases in serum transaminases in anti-FAS-treated mice when given at the same time as anti-Fas antibody (not shown). In contrast, they had no significant effect on the level of SGPT in the serum of LPS-treated mice (146 $\pm 32 \mathrm{U} / \mathrm{ml}$ in 10 mice treated with IDN 1529, $p=0.25 ; 91 \pm 25 \mathrm{U} / \mathrm{ml}$ in 9 mice treated with IDN 1965; $p=0.75$ ).

Haimovich-Friedman et al. (12) described endothelial apoptosis in a model of endotoxic shock similar to that used here. Given that IDN 1529 and IDN 1965 were both effective in preventing hepatic apoptosis following administration of anti-FAS antibody (not shown), we hypothesized that IDN 1529 may improve survival in endotoxic shock by preventing apoptosis in one or more cell types. Livers from LPS-challenged mice displayed a significant increase in TUNEL-positive endothelial cells, Kupffer cells, and, to a lesser extent, hepatocytes, compared to livers from mice injected only with saline (Fig. 5C). Administration of either IDN 1965 or IDN 1529 reduced LPS-induced hepatic TUNEL 


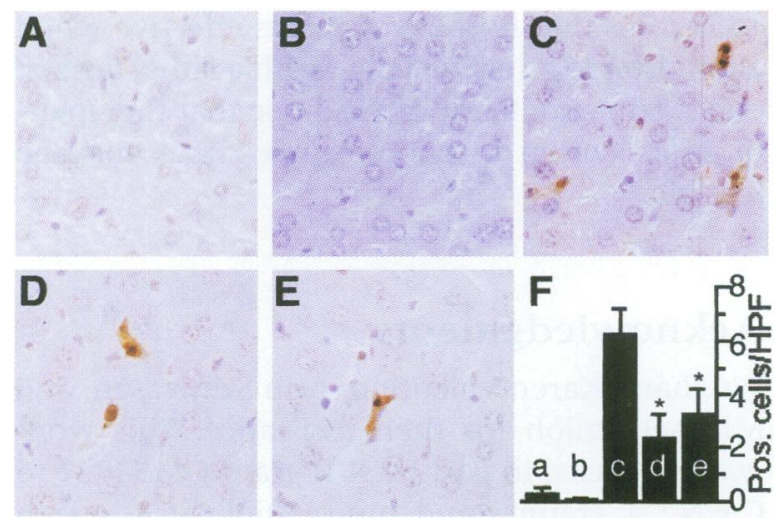

Fig. 5. Effect of peptidomimetic fluoromethylketones on LPS-induced hepatic apoptosis. Mice were injected ip with vehicle 1 (A) or LPS $(500$ $\mu \mathrm{g})$ in vehicle 1 (B-E), followed by 3 doses of vehicle 2 (B,C), IDN 1965 (10 mg/kg in vehicle 2) (D), or IDN $1529(10 \mathrm{mg} / \mathrm{kg}$ in vehicle 2) (E) at 4-hr intervals beginning $1 \mathrm{hr}$ after LPS. Livers were fixed $11 \mathrm{hr}$ after LPS challenge and subjected to TUNEL. (B) Negative control in which TdT was omitted. TUNEL-positive cells appear brown. (F) Quantitation of TUNEL-positive cells per $400 \times$ field. Lettering in $F$ refers to conditions described in A-E. Asterisks denote statistically significant $(p<0.05)$ reduction in TUNEL in livers from mice treated with either IDN 1965 or IDN 1529 compared to mice treated with vehicle. Results are pooled from two independent experiments; each bar represents $\geq 5$ mice. Sections were photographed at $400 \times$.

positivity (Fig. 5D,E). The comparable effectiveness of the two agents at reducing TUNEL positivity contrasted with their differential impact on survival. In the intestine, TUNEL positivity was not affected by either inhibitor, and TUNEL positivity in the kidneys and hearts of LPS-challenged mice was difficult to detect (not shown).

Caspases 2, 3, and 7 play important roles in apoptosis (reviewed in ref. 3). The tetrapeptide DEVD constitutes a consensus target site for cleavage by these enzymes. A caspase 3-like activity capable of cleaving the fluorescent substrate Ac-DEVD-AMC was increased 2 -fold in the livers of mice challenged with LPS (Fig. 6A) but not significantly in their intestines, kidneys, or lungs (Fig. 6B-D). Normal intestine had massive DEVD-AMCase activity compared to the other organs. IDN 1529 and IDN 1965 were equally efficacious in inhibiting DEVD-AMCase activity in all organs tested. Thus, both inhibitors were widely distributed in mice challenged with LPS and both had demonstrable caspase inhibitory activity in all organs tested.

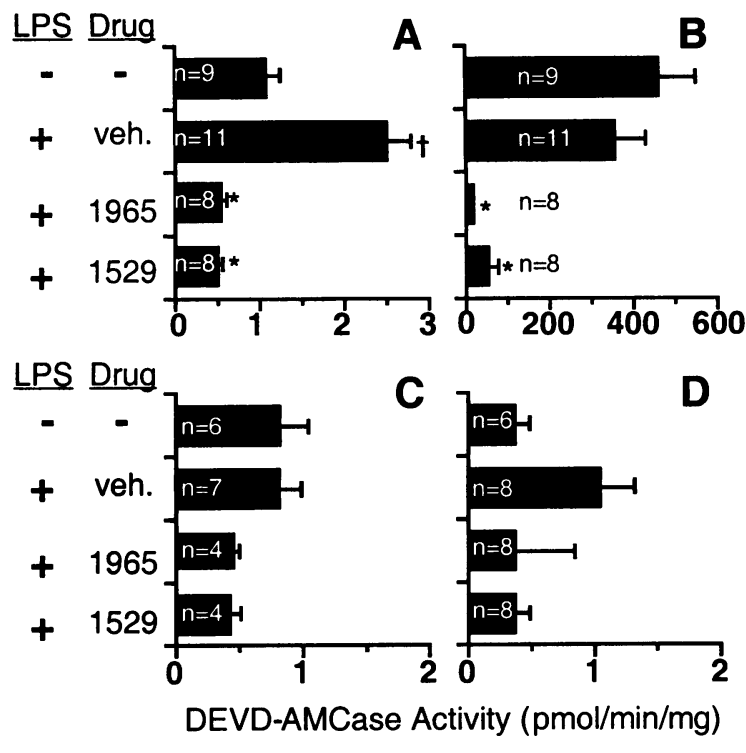

Fig. 6. Effect of treatment with peptidomimetic fluoromethylketones on caspase 3-like activity in organs of mice. Mice were challenged ip with vehicle 1 (-; see Materials and Methods) or LPS (+; $500 \mu \mathrm{g}$ in vehicle 1$)$, followed $1 \mathrm{hr}$ later by caspase inhibitor $(10 \mathrm{mg} / \mathrm{kg}$ in vehicle 2 ; see Materials and Methods) or vehicle 2 alone (veh.). Mice were sacrificed $11 \mathrm{hr}$ following LPS challenge and organ homogenates incubated with DEVD-AMC. (A) liver; (B) intestine; (C) kidney; (D) lung. *, statistically significant differences relative to LPS-challenged, vehicle-treated mice. ${ }^{+}$, significant difference $(p<0.05)$ relative to mice not given LPS. $n=$ number of mice per group. Results are pooled from three independent experiments.

\section{Discussion}

Antibodies against inflammatory agents or mediators [e.g., LPS (34), CDI4 (35), TNF (33), IFN- $\gamma$ (43)], organochemical antagonists [e.g., against platelet-activating factor (PAF) (36)], or cytokines [IL-l $\alpha(37)]$ have protected mice from endotoxic shock when given before or at the same time as LPS. Genetic deletion of cytokines and adhesion molecules has also been effective, but is likewise prophylactic (38). Only a few agents have shown efficacy when administered more than 30 min after LPS $(39,47,48)$. Thus, it is remarkable that IDN 1529 more than doubled the proportion of survivors when first given after LPS had already made the mice severely ill.

The protective effect of IDN 1529 overrode the presumably deleterious actions of the paradoxically and markedly elevated proinflammatory cytokines, IL- $1 \beta$, IL- $1 \alpha$, and IL-18. That a caspase 1 inhibitor led to an increase in the serum concentration of caspase 1-related cyto- 
kines provides the first evidence that some caspase inhibitors can exert diametrically opposite effects on cytokine levels in vitro and in vivo. The effects of IDN 1529 on the products of caspase 1 in vivo stand in sharp contrast to the effects of other caspase 1 inhibitors $(40-42)$. The effect of other ICE inhibitors on endotoxin-induced changes in serum IL- 1 has ranged from no effect (42) to a reduction (40). Importantly, none of these other caspase inhibitors have ever been shown to protect mice from death in experimental endotoxemia. Until it is known what structural features of the inhibitors or what aspects of the models lead to these divergent results, caspase inhibitors should be used with caution as anti-inflammatory agents in settings where elevations in IL-1 $\beta$, IL- $1 \alpha$, or IL-18 might be deleterious.

By what mechanism might a potent caspase 1 inhibitor elevate caspase 1 products? Our working hypothesis is that by inhibiting caspase 1 in vivo, IDN 1529 allowed LPS to induce the accumulation of pro-IL- $1 \beta$ and proIL-18 in macrophages. Inhibition of LPS-induced apoptosis of macrophages may have favored their subsequent LPS-induced necrosis, resulting in the release of pro-IL-1 $\beta$ and proIL-18 into the extracellular environment, where the pro-cytokines may have been partially processed by alternate routes. Noncaspases capable of processing IL- $1 \beta$ (43) and/or pro-IL-18 include plasmin, trypsin, chymotrypsin (25-27), granzyme A (44), and matrix metalloproteinases (45).

Given that IL- $1 \beta$, IL- $1 \alpha$, and IL- 18 were increased in the serum of IDN 1529-treated mice, a reduction in the net production of caspase 1-related proinflammatory cytokines cannot account for the survival benefit afforded by IDN 1529. Similarly, the equivalent ability of IDN 1529 and IDN 1965 to reduce LPS-induced hepatic caspase 3-like activity and apoptosis suggests that reduction in apoptosis alone was unlikely to account for the differential ability of IDN 1529 to improve survival in endotoxic shock.

These results suggest the presence of a previously unappreciated, late-acting, pharmacologically inhibitable death pathway in endotoxemia. A key catalyst in this pathway may be a novel caspase differentially susceptible to IDN 1529, or an enzyme of another class. Some peptidyl halomethyl ketones do react with proteins other than caspases (46). A search is underway for proteins differentially alkylated in vivo by IDN 1529 and not by IDN 1965. Meanwhile, IDN
1529 joins the short list of agents effective when administered after challenge with a lethal dose of endotoxin and it reawakens hope that therapeutic intervention in endotoxemic shock may be feasible.

\section{Acknowledgments}

We thank Karen Valentino, Anu Srinivasan, and Michael Shiloh for their assistance. This work was supported in part by NIH grant GM53921 to C.F.N.; a Trauma and Injury Biology Research Fellowship to S.R.G. via NIH training grant GM08466; NIH grant AR40135 to W.P.A.; and post-doctoral fellowships from Swiss National Science Foundation and la Foundation Suisse de Bourse de Medecine et Biologie to C.G.

\section{References}

1. Astiz ME, Rackow AC. (1998) Septic shock. Lancet 351: 1501-1505.

2. Salvesen GS, Dixit VM. (1997) Caspases: Intracellular signaling by proteolysis. Cell 91: 443-446.

3. Thornberry NA, Lazebnik Y. (1998) Caspases: Enemies within. Science 281: 1312-1316.

4. Li P, Allen H, Banerjee $S$, et al. (1995) Mice deficient in IL-1 beta-converting enzyme are defective in production of mature IL- 1 beta and resistant to endotoxic shock. Cell 80: 401-411.

5. Kuida K, Lippke JA, Ku G, et al. (1995) Altered cytokine export and apoptosis in mice deficient in interleukin-1 beta converting enzyme. Science 267: 2000-2003.

6. Wang S, Miura M, Jung YK, Zhu H, Li E, Yuan J. (1998) Murine caspase-11, an ICE-interacting protease, is essential for the activation of ICE. Cell 92: 501-509.

7. Gu Y, Kuida K, Tsutsui H, et al. (1997) Activation of interferon-gamma inducing factor mediated by interleukin-1 beta converting enzyme. Science 275: 206-209.

8. Ghayur T, Banerjee S, Hugunin M, et al. (1997) Caspase-1 processes IFN-gamma-inducing factor and regulates LPS-induced IFN-gamma production. Nature 386: 619-623.

9. Bohlinger I, Leist M, Gantner F, Angermuller S, Tiegs G, Wendel A. (1996) DNA fragmentation in mouse organs during endotoxic shock. Am. J. Pathol. 149: 1381-1393.

10. Haendeler J, Messmer UK, Brune B, Neugebauer E, Dimmeler S. (1996) Endotoxic shock leads to apoptosis in vivo and reduces $\mathrm{Bcl}-2$. Shock 6: 405409.

11. Hiramatsu M, Hotchkiss RS, Karl IE, Buchman TG. (1997) Cecal ligation and puncture (CLP) induces apoptosis in thymus, spleen, lung, and gut 
by an endotoxin and TNF-independent pathway. Shock 7: 247-253.

12. Haimovitz-Friedman A, Cordon-Cardo C, Bayoumy $S$, et al. (1997) Lipopolysaccharide induces disseminated endothelial apoptosis requiring ceramide generation. J. Exp. Med. 186: 1831-1841.

13. Ogasawara J, Watanabe-Fukunaga R, Adachi $M$, et al. (1992) Lethal effect of anti-Fas antibody in mice. Nature 365: 806-809.

14. Jaeschke H, Fisher MA, Lawson JA, Simmons CA, Farhood A, Jones DA. (1998) Activation of caspase 3 (CPP32)-like proteases is essential for TNF-alpha-induced hepatic parenchymal cell apoptosis and neutrophil-mediated necrosis in a murine endotoxin shock model. J. Immunol. 160: 3480-3486.

15. Armstrong RC, Aja T, Xiang J, et al. (1996) Fasinduced activation of the cell death-related protease CPP32 is inhibited by Bcl-2 and by ICE family protease inhibitors. J. Biol. Chem. 271: 1685016855.

16. Mittl PR, Di Marco S, Krebs JF, et al. (1997) Structure of recombinant human CPP32 in complex with the tetrapeptide acetyl-Asp-Val-Ala-Asp fluoromethylketone. J. Biol. Chem. 272: 6539-6547.

17. Perregaux D, Barberia J, Lanzetti AJ, Geoghegan KF, Carty TJ, Gabel CA. (1992) IL-1 beta maturation: Evidence that mature cytokine formation can be induced specifically by nigericin. J. Immunol. 149: 1294-1303.

18. Hogquist KA, Nett MA, Unanue ER, Chaplin DD. (1991) Interleukin $\mathrm{l}$ is processed and released during apoptosis. Proc. Natl. Acad. Sci. U.S.A. 88: 8485-8489.

19. Gabay C, Porter B, Fantuzzi G, Arend WP. (1997) Mouse IL-1 receptor antagonist isoforms: Complementary DNA cloning and protein expression of intracellular isoform and tissue distribution of secreted and intracellular IL- 1 receptor antagonist in vivo. J. Immunol. 159: 5905-5913.

20. de Olivera RM, Sipe JD, de Beer FC, et al. (1994) Rapid, sensitive enzyme-linked immunosorbent assays (ELISA) for serum amyloid A (apoSAA) in human plasma and tissue culture fluids. Int. J. Exp. Clin. Invest. 1: 23-29.

21. Wu JC, Fritz LC. (1999) A Companion to Methods in Enzymology. (in press).

22. MacMicking JD, Nathan C, Horn G, et al. (1995) Altered responses to bacterial infection and endotoxic shock in mice lacking inducible nitric oxide synthase. Cell 81: 641-650.

23. Krege JH, Hodgin JB, Hagaman JR, Smithies O. (1995) A noninvasive computerized tail-cuff system for measuring blood pressure in mice. Hypertension 25: 1111-1115.

24. Dinarello CA. (1997) Interleukin-1. Cytogenet. Gr. Fac. Rev. 8: 253-265.

25. Matshushima $K$, Taguchi M, Kovacs EJ, Young HA, Oppenheim JJ. (1986) Intracellular localiza- tion of human monocyte associated interleukin 1 (IL-1) activity and release of biologically active IL-1 from monocytes by trypsin and plasmin. $J$. Immunol. 136: 2883-2891.

26. Black RA, Kronheim SR, Cantrell M, et al. (1988) Generation of biologically active interleukin-1 beta by proteolytic cleavage of the inactive precursor. J. Biol. Chem. 263: 9437-9442.

27. Hazuda DJ, Strickler J, Kueppers F, Simon PL, Young PR. (1990) Processing of precursor interleukin 1 beta and inflammatory disease. J. Biol. Chem. 265: 6318-6322.

28. Gabay C, Smith MF, Eidlen D, Arend WP. (1997) Interleukin 1 receptor antagonist (IL-lRa) is an acute-phase protein. J. Clin. Invest. 99: 2930-2940.

29. Hirsch E, Irikura VM, Paul SM, Hirsh D. (1996) Functions of interleukin 1 receptor antagonist in gene knockout and overproducing mice. Proc. Natl. Acad. Sci. U.S.A. 93: 11008-11013.

30. Dinarello CA, Novick D, Puren AJ, et al. (1998) Overview of interleukin-18: More than an interferon-gamma inducing factor. J. Leukoc. Biol. 63: 658-664.

31. Puren AJ, Fantuzzi G, Dinarello CA. (1999) Gene expression, synthesis, and secretion of interleukin 18 and interleukin $1 \mathrm{~B}$ are differentially regulated in human blood mononuclear cells and mouse spleen cells. Proc. Natl. Acad. Sci. U.S.A. 96: 22562261.

32. Doherty GM, Lange JR, Langstein HN, Alexander HR, Buresh CM, Norton JA. (1992) Evidence for IFN-gamma as a mediator of the lethality of endotoxin and tumor necrosis factor-alpha. J. Immunol. 149: 1666-1670.

33. Beutler B, Milsark W, Cerami A. (1985) Passive immunization against cachectin/tumor necrosis factor protects mice from lethal effect of endotoxin. Science 229: 869-871.

34. McCabe WR, Greely A. (1972) Immunization with $\mathrm{R}$ mutants of $S$. minnesota I. Protection against challenge with heterologous gram-negative bacilli. J. Immunol. 108: 601-610.

35. Schimke J, Mathison J, Morgiewicz J, Ulevitch RJ. (1998) Anti-CD14 mAb treatment provides therapeutic benefit after in vivo exposure to endotoxin. Proc. Natl. Acad. Sci. U.S.A. 95: 13875-13880.

36. Casals-Stenzel J. (1987) Protective effect of WEB 2086, a novel antagonist of platelet activating factor, in endotoxic shock. J. Pharmacol. 135: 117122.

37. Silver GM, Gamelli RL, O'Reilly M, Hebert JC. (1990) The effect of interleukin 1 alpha on survival in a murine model of burn wound sepsis. Arch. Surg. 125: 922-925.

38. Guirao X, Lowry SF. (1996) Biologic control of injury and inflammation: Much more than too little or too late. World J. Surg. 20: 437-446.

39. Howard M, Muchamuel T, Andrade S, Menon S. 
(1993) Interleukin 10 protects mice from lethal endotoxemia. J. Exp. Med. 177: 1205-1208.

40. Fletcher DS, Agarwal L, Chapman KT, et al. (1995) A synthetic inhibitor of interleukin-1 beta converting enzyme prevents endotoxin-induced interleukin-1 beta production in vitro and in vivo. J. Interfon Cytokine Res. 15: 243-248.

41. Miller BE, Krasney PA, Gauvin DM, et al. (1995) Inhibition of mature IL- 1 beta production in $\mathrm{mu}$ rine macrophages and a murine model of inflammation by WIN 67694, an inhibitor of IL- 1 beta converting enzyme. J. Immunol. 154: 1331-1338.

42. Mignon A, Rouquet N, Fabre M, et al. (1999) LPS challenge in $\mathrm{D}$-galactosamine-sensitized mice accounts for caspase-dependent fulminant hepatitis, not for septic shock. Am. J. Respir. Crit. Care Med. 159: $1308-1315$.
43. Perregaux DG, Gabel CA. (1998) Post-translational processing of murine IL-1: Evidence that ATP-induced release of IL-1 alpha and IL-1 beta occurs via a similar mechanism. J. Immunol. 160: 2469-2477.

44. Irmler M, Hertig S, MacDonald HR, et al. (1995) Granzyme A is an interleukin 1 beta-converting enzyme. J. Exp. Med. 181: 1917-1922.

45. Schonbeck U, Mach F, Libby P. (1998) Generation of biologically active IL-1 beta by matrix metalloproteinases: A novel caspase-1-independent pathway of IL-1 beta processing. J. Immunol. 161: 3340-3346.

46. Schotte P, Declercq W, Huffel SV, Vanderabeele P, Beyaert R. (1999) Non-specific effects of methyl ketone peptide inhibitors of caspases. FEBS Lett. 224: 117-121. 